\title{
ECONOMIC AND SOCIO-POLITIC EFFECT OF MIGRATION ON BANGLADESH
}

\begin{abstract}
Mohammed Maksudur Rahman, M.Sc. (Polit.); Junior Researcher; Institute of Socio Political Research - Branch of the Federal Center of Theoretical and Applied Sociology of the Russian Academy of Sciences (ISPR FCTAS RAS);6 Fotievoy St., bldg. 1, Moscow, 119333, Russian Federation; E-mail: .m.rahman. akash@gmail.com
\end{abstract}

\begin{abstract}
Bangladesh is one of the major labor-sending countries of the world. Each year a huge number of people deliberately migrate overseas for both long- and short-term employment. This paper highlights the key impacts of migration including creating job opportunities for Bangladeshi workers and in making a significant contribution to the economy of Bangladesh. However, the paper also focuses on the negative aspects of international migration including exploitation of many migrant workers and the problems of not having provisions to protect their rights. Migration is a factor which affects both the sending and receiving countries. With the passage of time, as all types of migration increased significantly and it made vast socio-economic development of the area of destination through sending remittance. In Bangladesh, only international remittance has $6 \%$ share of total GDP (though it has several demerits like 'brain drain', 'lost labor' etc.). International migration has a significant impact on fertility pattern of Bangladesh.
\end{abstract}

Keywords: democracy; Remittances, skilled migration; economy; labor immigrants; Bangladesh.

Цитирование: Mohammed Maksudur Rahman. Economic and socio-politic effect of migration on Bangladesh // Наука. Культура. Общество. 2020. № 1. С. 107-118

Migration has transformed into a huge job methodology for the individuals of Bangladesh, considering its far-reaching financial improvement through moving of abilities, and network advancement. During the British period; individuals were moved to the United Kingdom and the USA for business, work and study purposes. In any case, the progression of relocation has been expanding in Center East nations since 1970, because of expanding oil reparation right now expanding the interest in human work power. Bangladesh ranks seventh in the list of the world's top remittance-receiving nations. In Bangladesh, global relocation is the significant driver of monetary advancement since it diffuses the information, innovation, thought, and aptitude.

At present, in Bangladesh, the complete populace is being assessed to 164.7 million, where work power in- vestment pace of the populace matured 15 or more established at 58.5 percent, at 81.9 percent male and 35.6 percent for females and 41.5 percent of the populace matured 15 or more seasoned outside the work power. In any case, 2.6 million individuals matured 15 or more established are as yet staying jobless (BBS, 2017). The greater part of them is uneducated and has extremely low aptitudes that are not reasonable for the neighborhood work showcase. The wages paid for these occupations is extremely low that it cannot support to lead their day by day occupation. The vast majority of the informed people cannot enter the activity advertise after the culmination of their training since they have no encounters and abilities identified with jobs. This labor can be an additional worthwhile they relocate to abroad as a laborer and make themselves as a benefit for the family and as well as for the nation too. 
Hence global migration which prompts stream the settlement can be a significant methodology for national improvement for Bangladesh. This paper attempts to investigate the significance of migration on the improvement of Bangladesh and furthermore clarifies the impact of migration on the financial improvement of Bangladesh.

\section{The origin of migrants}

Bangladesh has a long history of migration. Relocation to created and industrialized nations, especially in the West, was associated with the nation's provincial history. During the 18 and mid 19 century, mariners from the southeastern piece of East Bengal (Chittagong and Noakhali) secured positions in the English vendor naval force. An area of landless laborers from a locale in northern Sylhet, without work open doors for them, was caught up in the dockyards of Hooghly. Specialists presume that, in contrast to the mariners of Chittagong and Noakhali, this square didn't have a lot of nautical experience and escaped whenever the open door rose. They end-up in various nations including the US and the UK (Alam 1988). A large portion of these migrants have become long haul inhabitants, some received the citizenship of their goal nations. After the rise of Bangladesh in 1971, new open doors for worldwide relocation rose. With rising oil costs, the Center Eastern nations experienced a significant infrastructural improvement for which they required huge quantities of outcast laborers. Different classes of Bangladesh laborers joined the Center Eastern work showcase. Step by step, such movement likewise stretched out to the recently industrialized nations of Southeast Asia. Relocation for advanced education, which was uncommon previously, has gotten basic in the ongoing years.
Causes of International migration

Individuals of Bangladesh have moved from their nations of origin for a considerable length of time, for a wide range of reasons. Some are attracted to relocate by 'pull 'factors, others think that it is hard to stay at the home nation and move in view of 'push' factors. Push and pull factors end up being cut out of the same cloth: together they give the view of the contrast among «here» and «there», and in this way have a heuristic worth (McDowell and De Haan 1997). Individuals relocate on account of neediness, hunger, abuse, segregation, common war, joblessness and, all the more as of late, basically for training and better employment. The explanations for the worldwide movement of Bangladesh are sorted into two segments.

\section{Pull Factors}

- Employment opportunities in developed countries.

- The international transportation system has been easier than before.

- $\quad$ The Internet makes it easier to access information.

- Lower birth rates in developed countries pave the way to labor shortages and skills gaps.

- Rapid economic expansion requires extra people.

- Human rights and religious freedoms attract people to migrate.

- The young generation moves to get better jobs and improve their qualifications, as well as language skills.

\section{Push Factors}

- Lack of opportunities for career advancement

- $\quad$ Poverty and low incomes 
- $\quad$ Lack of employment opportunities

- Poor human rights.

- Internal conflict and political clash.

Environmental hazards like Natural disasters, climate change and famine Emigration from Bangladesh is basically for work. And works will professional or labor-related work. The \% of workers is $92 \%$ of total migrants from 1976 to 2013 as BMET ${ }^{1}$ says. Whereas only $2.4 \%$ for study but the dependency rate is higher than that of study rate. The dependency rate is $3.81 \%$. Only $1.8 \%$ emigrates for other reasons like living for treatment.

\section{Impacts on socio-economy as- pects of Bangladesh due to migration}

Experimental research on the financial and social effects of global relocation has multiplied during the most recent two decades (Greenwood and McDowell, 1986). Worldwide movement in Bangladesh has consistently been viewed as a critical issue for financial and social improvement. Universal movement plays a fundamental and ineluctable job in the national economy of Bangladesh in two different ways. Right off the bat, it limits joblessness. Furthermore, worldwide relocation brings about settlement stream to the nation, which serves a critical however costly wellspring of muchrequired outside trade.

Reduce Unemployment: It is expected that $33 \%$ of the all-out workingage populace of Bangladesh is experiencing either joblessness or underemployment. Relocation has kept the pace of joblessness practically unaltered since the 1980s, despite the fact that the development pace of the work

${ }^{1}$ BMET: Bureau of Manpower, Employment and Training powers more (twice) than that of the populace development. In this manner, relocation limited the weight of substitute work creation on progressive governments.

Remittance: Migrants remittance represents a major segment of the nations' trade income. This has been utilized to back the import of crude materials and capital products for mechanical progression. The consistent progression of settlements has settled outside trade challenges, builds up the parity of installments and assisted with expanding the inventory of national reserve funds. The commitment of foreign aid during the 1990s was the greater part of the national development budget. Remittance as of late comprised a bigger segment of the nation's advancement budget plan.

Remittance and trade: In spite of the fact that remittance impacts affect the financial improvement of this nation, it might effectively affect exchange and business in accepting nation. Be that as it may shows that remittance have the antagonistic impact of on exchange intensity of Bangladesh since laborers settlement is broadly utilized for the non-tradable division as employments and better personal satisfaction, yet not utilized for the tradable area

Transmission of Culture: Migration prompts social transmission as Bangladeshi individuals move to different nations and become used to different societies through movement. Through global relocation, culture transmitted by information, language, ancient rarities, and numerous other material items. Individuals from Bangladesh, relocating to different nations, meet various standards and estimations of various social orders. Inevitably which influence their family and public activity when they come back to Bangladesh. 
Change in Family Structure: Relocation significantly affects the richness example of Bangladesh. Culturally diverse information assists with growing and builds up the standpoint of the individuals, which assists with making mindful about the size of the family. Relocation impacts family structure, both in goal and inception territories. Dominatingly it is seen that relocated bread proprietors of a family take fewer kids. Albeit numerous vagrants are less taught or not instructed by any stretch of the imagination, they give more consideration to the benefits of training and the soundness of their kids.

Social Infrastructural Development: Migrants put their settlement being developed ventures, religion focuses, independent ventures, medical clinics, streets, schools. Therefore, the neighborhood infrastructural advancements improve. At present in excess of 215 million individuals who live in various nations for better monetary chances (World Bank, 2011). Remittance is utilized for the advancement of vagrant's expectations for everyday comforts. The framework of our nation is improving step by step.

Improvement of Social Status: Worldwide migrants significantly affect the accomplishment of the economic wellbeing of migrants. New qualities, new propensities, utilization example and ownership of various products carry a higher societal position to the migrants. Their cooperation in different social exercises, associations and social mindfulness gives them an improved personality in the general public. Non-transient Individuals are impacted by the demeanor of vagrants and benefit them in a profound position.

\section{Significance of international mi- gration: Positive}

The global movement presents critical monetary increases for vagrants, their nations of the cause, and their nations of goal. Migrants offer different advantages to the host nations, for example, doing tasks that individuals in the host nation won't, or can't do; migrated laborers frequently work longer hours and for lower pay rates; they add to the decent variety of that society, which can help with resilience and comprehension; for the host nation's economy, immigrants offer an expanded ability pool, on the off chance that they have been knowledgeable in their sending nation or later taught in the host nation.

Settlements and a potential 'mind increase' through a counter-development of abilities and information are valuable to the national advancement of both sending and getting goals. The advantages got from this development impacts affect the prosperity of transients and as it's easing neediness of their adoration ones remaining behind. This inflow of remittance to Bangladesh throughout the years has mostly turned the "brain drain" into cerebrum gain as it assumes a significant job in improving individual living conditions and destitution lightening crediting more businesses and job opportunities for the mainland

The movement into the different countries has contributed towards security and political steadiness by lessening destitution levels, checking joblessness and growing the encounters and chances to the populace. As indicated by the World Bank, the resettlement of the skilled workforce movement can help ease work pressures from Bangladesh. Many developing na- 
tions think that it's hard to profitably utilize all skilled specialists in light of little economies of scale. Universal relocation has throughout the years been retaining an impressive number of youngsters entering their work markets from the sending regions, while likewise producing huge progressions of settlements.

In any case, for the significant migrating source nations, migration is by and large observed as making a net commitment to advancement.

\section{Significance of international mi- gration: Negative}

International migrant workers are exposed to a mess of problematic situations affecting the migration process from its embryonic stage until return to the country of origin. Though both men and migrant women workers are confronted with myriads of vulnerabilities, the undeniable truth is that the position of migrant women workers, compared to it of men, is more vulnerable. the explanation why women often find themselves in situations of vulnerability is owing to the actual fact that gender-based discrimination and violence are perpetrated against them. Therefore, migrant women workers are in peril of getting exposed to confiscation of travel documents, withholding and nonpayment of salary or salary reduction, harsh working conditions, lack of freedom of movement and communication, etc. in certain countries. Additionally, verbal, physical, and sex offense within the course of their working life appears to be a really common and distressing reality of female migration.

In spite of the huge capability of relocation for advancement, one can't deny that worldwide relocation may likewise cause negative ramifications, which should consider truly. These remember negative impacts for the security, wellbeing, and prosperity of vagrants because of lacking rights arrangement and to ensure the privilege of the migrants. Others may identify with financial impacts for sending social orders, for example, 'lost labor", 'brain-drain', or to the conceivable negative impact on the mental parts of kids because of the relocation of their parents. In Bangladesh, social wonders, for example, an expansion in separations and elopement of spouses have been related to elevated levels of male outward relocation. Regardless of whether the financial effect is sure in getting nations relies upon the match among abilities and work advertise needs and the manner in which vagrants are incorporated with the host nation. However, negative relationship with portability and relocation are not constantly founded on sound investigation and are regularly misused for political purposes in created and creating nations.

Instead of reacting to negative impacts by setting up further limitations on relocation and portability, active negative wonders related with movement ought to be considered while planning approaches.

In table- 1 we can see that the financial year 2007-08, around 9,81,000 specialists were utilized abroad, yet the pattern was diminishing in FY 2010 11 , which represented $4,39,000$. In any case, the monetary year 2011-12, the measure of laborer's work abroad ascended to $6,91,000$. Nonetheless, as of late, the transient specialist assessed $9,05,000$, which was higher than the earlier year, which was a record for $6,85,000$. 


\section{Remittance flows in Bangladesh}

Table 1.

Remittance flows in Bangladesh

\begin{tabular}{|l|l|l|l|}
\hline FY & $\begin{array}{l}\text { No } \\
\text { Employment }\end{array}$ & of & Amount of remittance \\
\hline & Abroad 000 & In Million USS & $\begin{array}{l}\text { Percentage } \\
\text { Change \% }\end{array}$ \\
\hline $2007-08$ & 981 & 7914.78 & 32.39 \\
\hline $2008-09$ & 650 & 9689.16 & 22.42 \\
\hline $2009-10$ & 427 & 10987.40 & 13.40 \\
\hline $2010-11$ & 439 & 11650.32 & 6.03 \\
\hline $2011-12$ & 691 & 12843.40 & 10.24 \\
\hline $2012-13$ & 441 & 14461.15 & 12.60 \\
\hline $2013-14$ & 409 & 14228.30 & -1.61 \\
\hline $2014-15$ & 461 & 15316.91 & 7.65 \\
\hline $2015-16$ & 685 & 14931.14 & -2.52 \\
\hline $2016-17$ & 905 & 12769.5 & -14.48 \\
\hline
\end{tabular}

Source: Bangladesh Economic Review

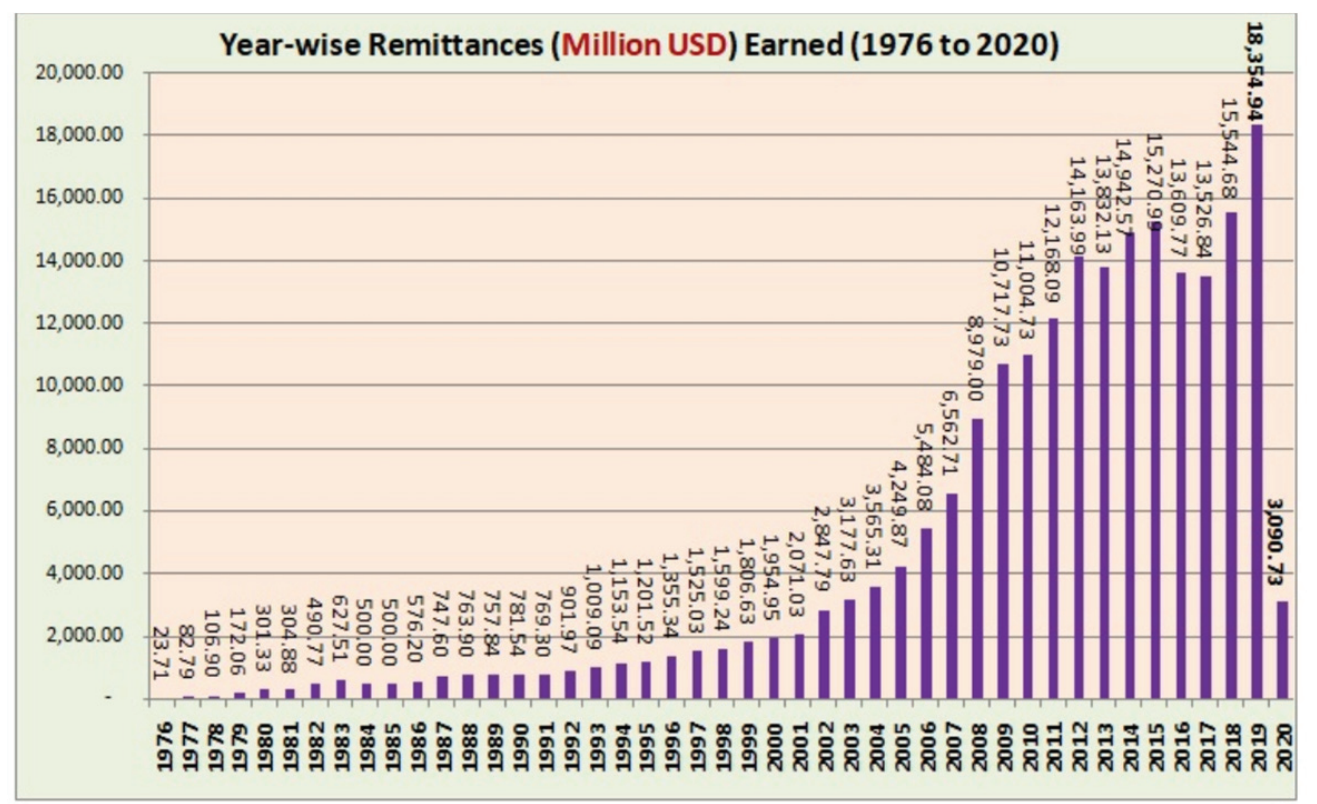

Figure - 1: Remittance flow to Bangladesh year wise

Source: Bureau of Manpower Employment and Training (BMET) (http://www.old.bmet.gov.bd/ BMET/stattisticalDataAction)

In 2007-08 periods, the remittance earned was USD 7914.781 million, from that point onward; the pattern was steadily expanded up to the financial year 2014-2019 period, which represents US 15316.91 million. The most noteworthy remittance earned in 201918354.94 million USD. As 
of late, the table uncovers that US dollar 12769.5 in million settlements have been earned in 2015-2016 by the province which is lower than the earlier year (US 14931.14) million of every 2016-17. He latest 2019 had a reach of 18,354.94 million USD. In figure 1 we can see in 2019 highest remittance came of 2982 million USD from K.S.A (Saudi Arabia), next to it highest remittance was 2259.47 million USD from U.A.E (United Arab Emirate). Kuwait, Oman, Qatar, Malaysia, U.S.A, U.K. and other countries also has significant contribution to remittance inflow of Bangladesh.

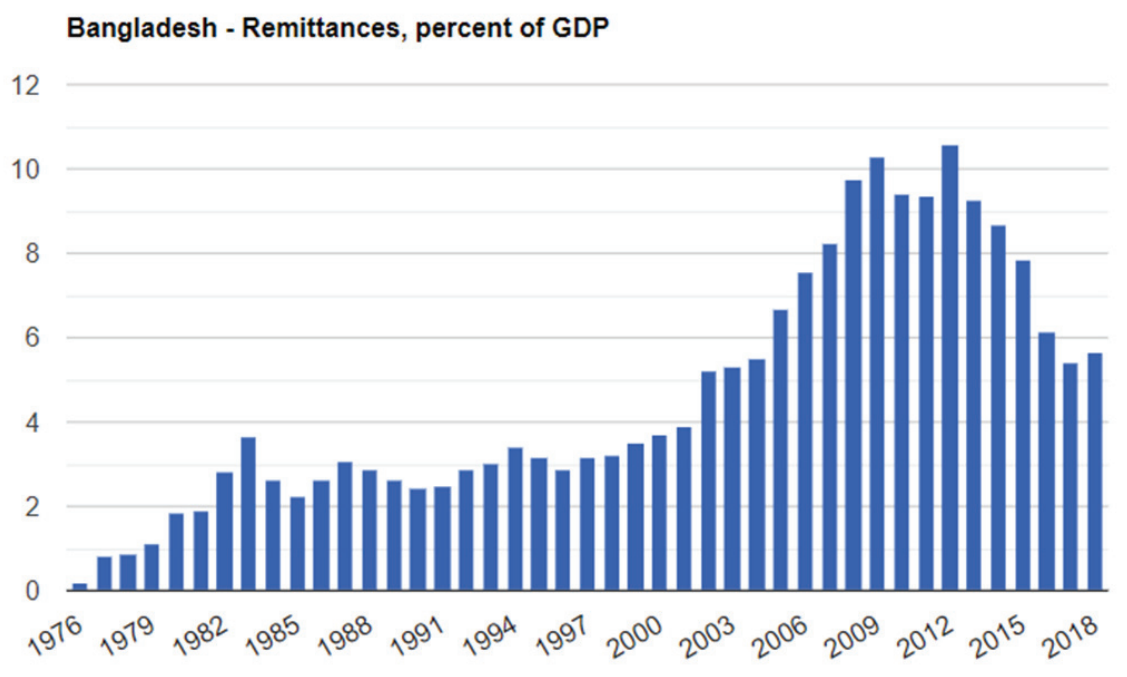

Figure - 2: Bangladesh: Remittances, percent of GDP

Source: The World Bank (https://www.theglobaleconomy.com/Bangladesh/remittances_percent_ GDP/)

The World Bank gives data for Bangladesh from 1976 to 2018. The average remittance value Bangladesh received during 1976 to 2018 is 4.61 percent of total GDP. The minimum of 0.19 percent in 1976 and the maximum remittance recorded was 10.59 percent in 2012. The latest value recorded from 2018 is 5.68 percent.

\section{Major trends of migration from Bangladesh}

Since 1976, there has been consistent development in worldwide migration from Bangladesh. During the Primary decade (1976-1985), a normal of 41,000 Bangladeshis sought after universal work movement yearly. This figure bounced to a yearly normal of 137,000 during the subsequent decade
(1986-1995), to 240,000 in the third decade (1996-2005), and 552,000 during the fourth decade (2006-2015). In 2008, a record number of 875,055 Bangladeshis traveled to another country for work purposes. After a concise time of variance from 2009 to 2013, the example has reliably expanded again beginning in 2014, arriving at the most elevated yearly pace of $1,008,525$ out of 2017. (The worldwide monetary downturn, political choppiness in the Center East, and embargoes by a few enrollments of Bangladeshi migrants seemed to negatively affect the outflow of work movement from Bangladesh somewhere in the range of 2009 and 2014. After that from 2015 the trend of going abroad has increased again. 
In 2019 it was 700,159. Till February 2020 worldwide human capital migrated was 129,127 . However with the development of global pandemic COVID-19 ratio of migration are expected to be low this year.

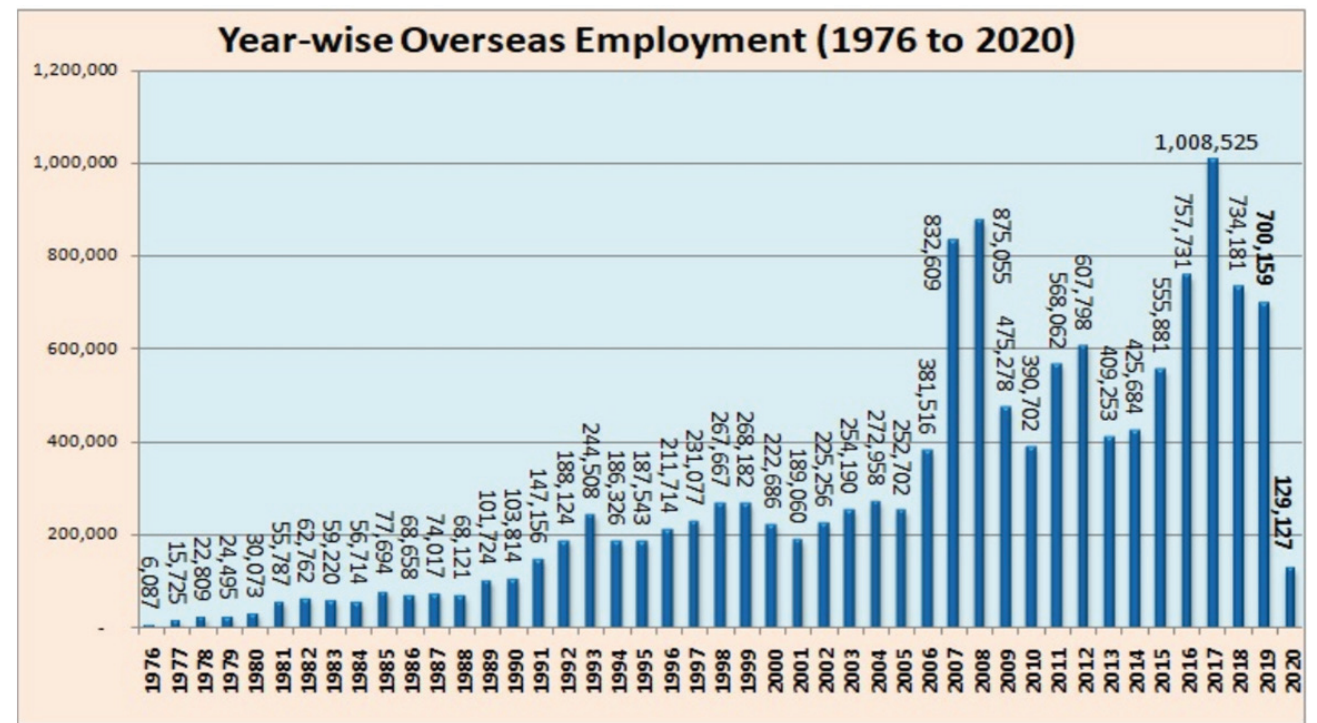

Figure - 3: Migrants flowes of Bangladesh

Source: Bureau of Manpower Employment and Training (BMET) (http://www.old.bmet.gov.bd/ BMET/stattisticalDataAction)

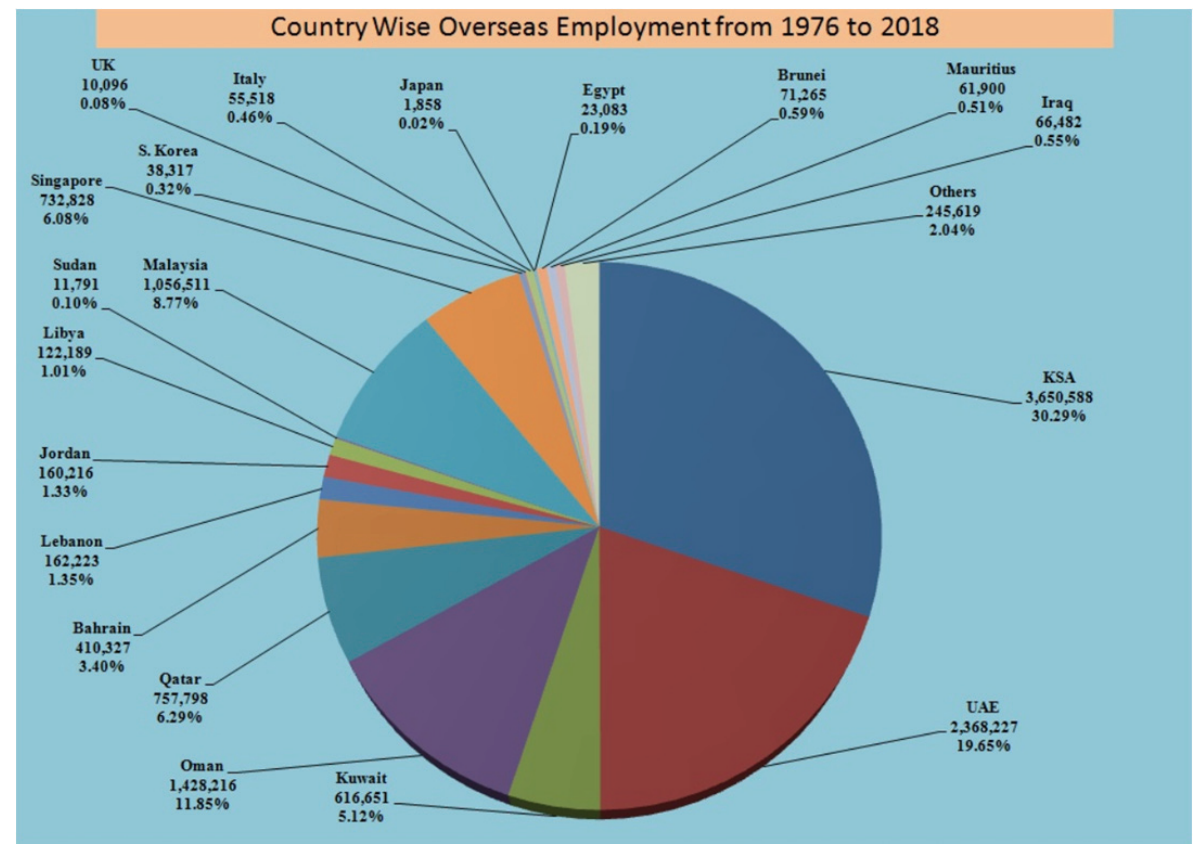

Figure - 4: Popular countries for Migrants of Bangladesh

Source: Bureau of Manpower Employment and Training (BMET) (http://www.old.bmet.gov.bd/ BMET/stattisticalDataAction) 
The Center East and SouthEast Asia are the significant goals of Bangladeshi migrant workers. The top goal nations are Saudi Arabia $30 \%$, the United Arab Emirates 19.65\%, Oman 11.85\%, Malaysia 8.77\%, Qatar 6.29\% and Singapore $6.08 \%$. Most of these migrated persons are skilled migration for work. Except this USA, UK, Canada and Australia has been quite popular among migrants at present for study and work.

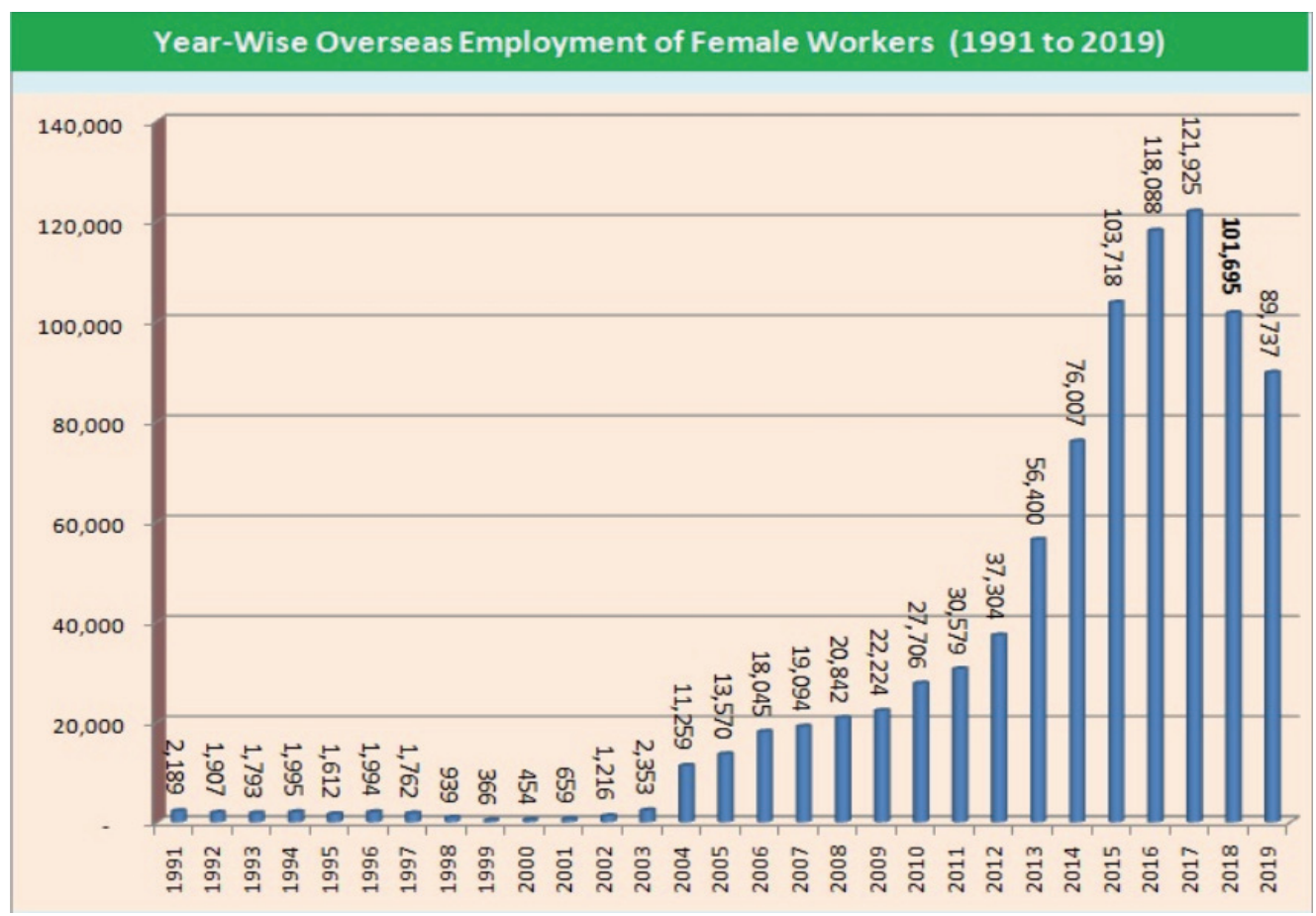

Figure - 5: Popular countries for Migrants of Bangladesh

Source: Bureau of Manpower Employment and Training (BMET) (http://www.old.bmet.gov.bd/ BMET/stattisticalDataAction)

Female works also started to migrate from 1991 .We can see in the starting years it was around 10002000 lady works going abroad yearly for work. However we can see a drastic increase of female migrants from 2004 yearly more than 11000 female works went abroad for work. Highest recorded was in 2017 with a number of 121,925 female migrants. As we can see Saudi Arab has been most popular destination for female works as well like male works. UAE, Qatar, Lebanon, Oman and other counties got popular destination for female works from Bangladesh. 


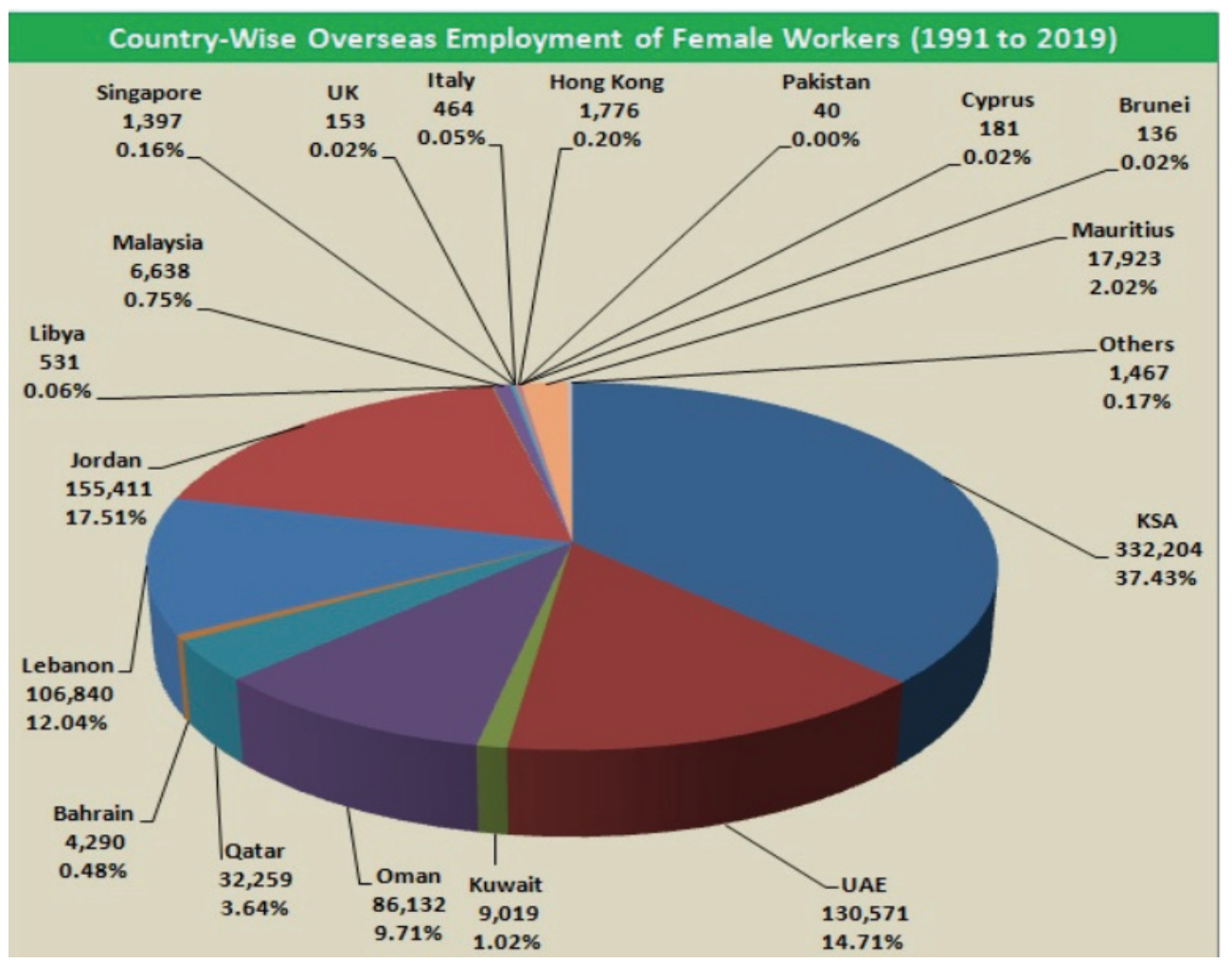

Figure - 6: Popular countries for Migrants of Bangladesh

Source: Bureau of Manpower Employment and Training (BMET) (http://www.old.bmet.gov.bd/ BMET/stattisticalDataAction)

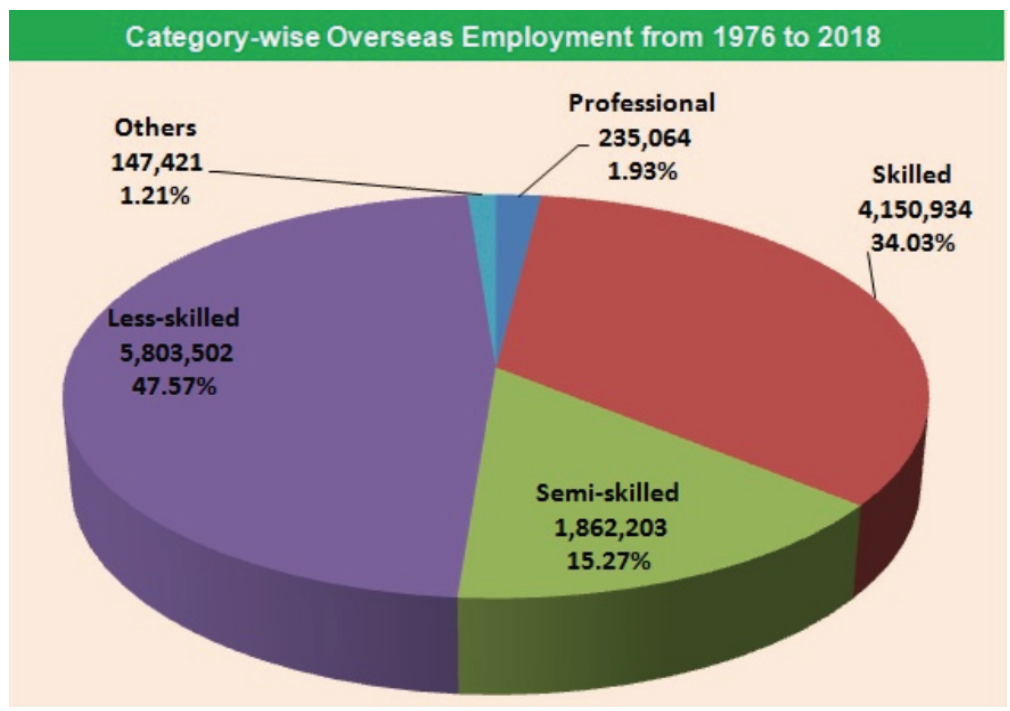

Figure - 7: Deviation of Migrants of Bangladesh based on work skill

Source: Bureau of Manpower Employment and Training (BMET) (http://www.old.bmet.gov.bd/ BMET/stattisticalDataAction) 


\section{Government planning for attrac- ting more foreign investors on labor market}

Bangladesh is one of the seven highest remittance receiving country of the world. As for less job opportunity in the country government is also praising the labor market for migrate which will benefit the economy. As most of the migrated workers are less skilled $47.57 \%$ so the government is trying to solve that problem to attract more work opportunities from other countries. In addition, different focuses of plan, for example, gender-specific explicit results. One is the requirement for a comprehensive and gender-specific delicate specialized and professional instruction and preparing (TVET) ${ }^{1}$ projects to give the two people the aptitudes expected to satisfy work advertise need, which has evident connects to the work relocation. As the Point of view Plan puts it, the point is to «give ladies their legitimate offer in aptitudes advancement preparing both at home and abroad and to improve proficient greatness». What's more, another objective with bearing on work relocation is identified with fortifying the exchange related stock side limits of Bangladesh. Certain businesses, for example, the readymade piece of the clothing industry, have risen as significant providers of worldwide brands. Such parts would profit fundamentally from a talented work power, and accordingly, hold the great potential to advance the expert reintegration of returning transient specialists. Checking the arrival examples and profiles of returning vagrant ladies laborers and the improvement of appealing social and expert reintegration projects would add to the acknowledgment of the overall objective to build

${ }^{1}$ TVET :Technical and Vocational Education and Training sends out from Bangladesh to around 38 percent of Gross domestic product by 2021. Moreover, the Point of view Plan likewise takes note that the «Bangladesh economy is more incorporated with the worldwide market today than any other time in recent memory». The Point of view Plan credits this circumstance to «fast development in exchange, enormous out-movement of work and remittance inflows yearly settlement streams remains at almost US $\$ 14.2$ billion. Remittances have gotten an asset of significant significance and have risen as a noticeable wellspring of remote trade. The Point of view Plan, in this way, centers on the moves identified with relocation and focuses on certain methodologies to address those difficulties and let the advancement procedure flood ahead.

\section{Conclusion}

Bangladesh is one of the highest work sending nations in the world. Work relocation, significant methods for globalization, is the most popular way for the financial advancement of the nation. Thus, Bangladesh should find a way to create ability labor through legitimate preparation. It is a crying requirement for Bangladesh to guarantee a high chance for its migrating works before sending them to another country to make them ready to procure attractive sum, and in this manner send an expanded measure of remittance to home.

To conclude, International migration has positive impacts on socio-economic development in Bangladesh. IT is not only the direct remittances that help the government to develop the economy of Bangladesh but also the Business opportunity that a migrant brings with which the economy of Bangladesh gets to stand in its own feet. 


\section{References}

1. McDowell, C. and De Haan A.(1997). MIGRATION AND SUSTAINABLE LIVELIHOODS: A CRITICAL REVIEW OF THE LITERATURE , IDS Working Paper 65

2. Sarker, M. \& Islam, S. (2018). Impacts of International Migration Socio-Economic Development in Bangladesh. European Review of Applied Sociology, Vol. 11, No. 16 Year 2018

3. Adams Jr, R. H., \& Cuecuecha, A. (2010). Remittances, household expenditure and investment in Guatemala. World Development, 38(11), 1626-1641.

4. Alam, F (1988) 'Salience of Homeland: Societal Polarization within the Bangladeshi Population in Britain', Research Papers in Ethnic Relations, No. 7, Centre for Research in Ethnic Relations, Economic and Social Research Council (ESRC), University of Warwick.

5. Akter, S. (2016). Remittance Inflows and Its Contribution to the Economic Growth of Bangladesh. : Bangladesh bureau of statistics (BBS), (2016). Report of The Survey on Investment from Remittance 2016 (visited in 17 March 2020)

6. Bangladesh Bureau of Statistics (BBS) (2017). Bangladesh labor force survey. Bangladesh Economic Review, 2017 (visited in 17 March 2020)

7. Bureau of Manpower Employment and Training (BMET) http://www.old.bmet.gov. bd/BMET/stattisticalDataAction (visited in 17 March 2020)

8. Chowdhury, M. B. (2011). Remittances flow and financial development in Bangladesh. Economic Modelling, 28(6), 2600-2608.

9. Chowdhury, M. B., \& Rabbi, F. (2014). Workers' remittances and Dutch disease in Bangladesh. The Journal of International Trade \& Economic Development, 23(4), 455-475.

10. Farid, K. S., Mozumdar, L., Kabir, M. S., \& Hossain, K. B. (2009). Trends in international migration and remittance flows: Case of Bangladesh. Journal of the Bangladesh Agricultural University, 7(2), 387-394.

11. Haider, M. Z., Hossain, T., \& Siddiqui, O. I. (2016). Impact of remittance on consumption and savings behaviour in rural areas of Bangladesh. Journal of Business, 1(4), 25-34.

12. Hatemi-J, A., \& Uddin, G. S. (2014). On the causal nexus of remittances and poverty reduction in Bangladesh. Applied Economics, 46(4), 374-382.

13. Paul, B. P., \& Das, A. (2011). The Remittance-GDP Relationship in the Liberalized Regime of Bangladesh: Cointegration and Innovation Accounting. Theoretical \& Applied Economics, 18(9).

14. Pradhan, M. A., \& Khan, G. U. (2015). Role of Remittance for improving quality of life: Evidence from Bangladesh. Turkish Economic Review, 2(3), 160.

15. Sarker, M., \& Islam, M. S. (2014). Husbands' international labour migration and the change of wives' position among the left-behind in rural Bangladesh. ISSN (Paper), 2224-5766.

16. Siddique, A., Selvanathan, E. A., \& Selvanathan, S. (2012). Remittances and economic growth: empirical evidence from Bangladesh, India and Sri Lanka. Journal of development studies, 48(8), 1045-1062. 